\title{
A Phenomenological Study on Voluntarily Childless Women
}

\section{Gönüllü Çocuksuzluğu Tercih Eden Kadınlar Üzerine Fenomenolojik Bir Araştırma}

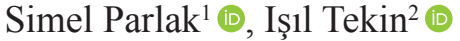

'Dr., Okan University, Faculty of Education Sciences, Guidance and Psychological Counseling, İstanbul, Turkey

${ }^{2}$ Dr., Istanbul Medeniyet University, Faculty of Educational Sciences, Guidance and Psychological Counseling, İstanbul, Turkey

ORCID: S.P. 0000-0002-8651-2693 I.T. 0000-0002-3369-4083

\section{Corresponding author/Sorumlu yazar:} Ișıl Tekin,

Istanbul Medeniyet University, Faculty of Educational Sciences, Guidance and Psychological Counseling, İstanbul, Turkey E-mail/E-posta: tekinisil1@gmail.com

Submitted/Başvuru: 14.04.2019 Revision Requested/Revizyon Talebi: 17.04.2019

Last Revision Received/Son Revizyon:

11.04.2020

Accepted/Kabul: 14.04.2020

Published Online/Online Yayın: 28.04.2020

Citation/Atıf: Parlak, S. \& Tekin, I. (2020). A phenomenological study on voluntarily childless women. Psikoloji Çalışmaları Studies in Psychology. Advance online publication.

https://doi.org/10.26650/SP2019-0034

\begin{abstract}
The way in which women decide to have children is affected by many processes, including personal, social, historical, and political. Maternity is seen as an inevitable part of women's happiness and a complement to their femininity. In traditional Turkish family structure, femininity is sanctified through maternity, and the status of women in the family and society is shaped by whether they have children or not. The status of women began to change with urbanization and also by virtue of women's increasing participation in the workforce. The idea began to be expressed that maternity is not necessarily the fate of women, and given that it is a preference, which includes not only satisfaction but also difficulty, childlessness might be preferred. This study aims to examine the voluntary childlessness preferences of women. For this purpose, the study group consisted of four married women, who currently do not have children and who prefer not to have children. The age of the participants varies between 30 and 40 years and they are all voluntary. The study is designed according to descriptive phenomenology design of qualitative research methodology. The data were collected through semi-structured in-depth interviews. In the analysis of the data, Colaizzi's (1978) phenomenological analysis steps were followed. During the interviews, it was seen that participants emphasized the concepts of responsibility and care giving. As a result of the analysis, it appears that the data are combined under the following themes: the meaning of maternity, the meaning of the concept of maternity in social circles, the meaning of not wanting a child, effects of voluntary childlessness, the decision of voluntary childlessness, social reactions to voluntary childlessness, and dilemmas experienced in the face of voluntary childlessness. It was observed that instinctive attitudes about maternity and perceptions on child bearing are still ongoing, that the pressure of being a mother has been preserved in the social environment, and that voluntarily childfree women define childlessness as freedom in many areas of life. With this study we make a contribution to the literature by attending to the voice of voluntarily childless women in the context of a woman's right to decide on her own body.
\end{abstract}

Keywords: Woman, maternity, childlessness, voluntary childlessness 


\section{öZ}

Kadınların çocuk sahibi olmaya dair kararlarına bakıldığında bu kararların; kişisel, sosyal, tarihi hatta politik pek çok süreçten etkilendiği görülmektedir. Annelik, kadınların mutluluğunun kaçınılmaz bir parçası ve kadınlıklarının bir tamamlayıcısı olarak kabul edilmektedir. Geleneksel Türk aile yapısına bakıldığında kadınlık, annelik üzerinden kutsallaştırılmakta ve kadının aile içindeki ve toplumdaki statüsü çocuk sahibi olup olmadığına göre şekillenmektedir. Kentleşme ve iş gücüne katılım ile birlikte kadının statüsü değişmeye başlamıştır. Anneliğin kadınların kaderi olmadı̆̆ı, tatmin içermesinin yanı sıra zorluk da içeren bir tercih olduğu görüşü, dolayısıyla çocuksuzluğun tercih edilebileceği dile getirilmeye başlanmıştır. Bu çalışma kadınların gönüllü çocuksuzluk tercihlerini incelemeyi amaçlamaktadır. $\mathrm{Bu}$ amaç doğrultusunda çalışma grubu evli olan, mevcut durumda çocuk sahibi olmayan ve çocuk sahibi olmamayı tercih eden dört kadından oluşturulmuştur. Yaşları 30 ile 40 arasında değişen katılımcıların seçiminde gönüllülük esas alınmıştır. Çalışma nitel araştırma yönteminden biri olan betimleyici fenomenoloji desenine uygun olarak tasarlanmıştır. Veriler, yarı yapılandırılmış derinlemesine görüşmeler gerçekleştirilerek toplanmış ve verilerin analizinde Colaizzi’nin (1978) fenomenolojik analiz adımları takip edilmiştir. Görüşmeler sırasında sorumluluk ve bakım verme kavramlarının vurgulandığ1 görülmüştür. Analiz sonuçlarına göre verilerin anneliğin anlamı, annelik kavramının sosyal çevredeki anlamı, çocuk istememenin anlamı, gönüllü çocuksuzluğun etkileri, gönüllü çocuksuzluk kararı, çocuk sahibi olmama konusunda çevrenin tepkileri ve çocuk sahibi olmama kararına ilişkin ikilemler temaları altında toplandığı görülmüştür. Bu çalışmada annelik ve çocuk sahibi olma algısı konusunda içgüdüsel düşünüşün devam ettiği, sosyal çevreden anneliğe yönelik baskı unsurunun varlığını koruduğu ve gönüllü çocuksuz kadınların çocuksuzluğu yaşamın birçok alanında özgürlük olarak tanımladığı gözlemlenmiştir. Kadının kendi bedeni üzerindeki karar hakkını görünür kılmada gönüllü çocuksuz kadınların sesi literatüre taşınmıştır.

Anahtar Kelimeler: Kadın, annelik, çocuksuzluk, gönüllü çocuksuzluk 
Socio-political and cultural resources shape women's decisions about having and raising children. Macro-level changes such as improvements on fertility, increased participation in the workforce, and women's rights movements present new opportunities for women and determine their choice as to whether they will be mothers (Settle $\&$ Brumley, 2014). The women's freedom movement has opened up a political space and led scholars to think about where motherhood comes from. This movement first fought against the maternal myth, namely that the inevitable destiny of women and women's happiness stems from motherhood. It also emphasizes that motherhood is a matter of both pressure and satisfaction, and that this should be a free choice (Rowbotham, 1989).

In Turkey, couples are expected to have children after marriage as part of the normal, expected pattern of life. Women encounter intense pressure to have children (Koçyiğit, 2012). In terms of social norms, the way to be a woman is through being a mother (Sever, 2015). Despite all these social norms, there are women who choose childlessness. Therefore, the phenomenon of voluntary childlessness is noteworthy.

Childless women feel unrecognized and are aware that their social environment has difficulty in accepting their preferences (Blackstone \& Stewart, 2012; Özbay, 2014). The aim of this study is to reveal the social and individual experiences of voluntarily childless women who are few in number. The study aims to understand the perceptions of childless married women regarding the meaning of motherhood and also to comprehend their decision not to have children.

\section{Voluntary Childlessness}

The decision to have a child or not is a complex phenomenon involving the individual's various social processes and identities (Blackstone \& Stewart, 2012). Given public developments regarding maternity and childbirth, childbirth is considered a national duty because of the serious human loss in the First World War. It is seen that with the industrial revolution and the Second World War, women started to take part in the labor market (Costa, 2000; Goldin, 1991). However, in the workers' movement, it is emphasized that women's employment poses a threat to the working class, and that the task of women is restricted to children's care and to the home, and that femininity and maternity are regulated. Social debate and changes about pregnancy continue to be discussed today (Collin \& Kaufer, 2015). 
Looking at the literature, at the beginning of the 1970s, the focus was on heterosexual women who wanted to have many children but could not, rather than on women who volunteered not to have children. In that period it was regarded as a contradiction not to have children (Blackstone \& Stewart, 2012). In the nineteenth century, childfree women began to be defined as problematic individuals with psychological distress, while maternity was shown as a way of happiness and personal satisfaction (Çeler, 2013).

When we look at the approach of the feminist movement towards maternity, it seems that it passes through two main lines. First there is the attribution of complementarity to the maternity of women, and the other is that with the 70s it was necessary to move on to becoming equal to men who develop in their careers without concern about the continuity of the generation in society. In the feminist view on maternity, the emphasis is placed on both the rejection of the compulsory mother and the desire to become a mother voluntarily (Collin \& Kaufer, 2015). The choice is left to women between seeing maternity as an obstacle and seeing it as a symbiotic relationship in addition to a consensus on the rejection of the compulsory mother (Badinter, 1992). Simone de Beauvoir is seen among the representatives of those who see maternity as an obstacle, and she states that the masculine model must be adopted for women to be equal with men (as cited in Collin \& Kaufer, 2015). Luce Irigaray emphasizes the shaping and semiotic side of her motherhood (as cited in Withford, 1991). Caroline Gilligan (1982), also emphasizes the creative aspect of care and maternal care of maternity.

When we look at the psychology literature, it is clear that information about woman is formed by men and by the law of man. The term phallus defines women's position and social law (Badinter, 1992; Çeler, 2013). The Freudian approach, which explains female sexuality in terms of impulse, states that the way to compromise female phallus craving and biological humiliation is to be a mother. The Freudian approach implies that the only way to overcome penis longing and despair is to have children and that the adoption of an attitude other than this will lead to the failure and neurosis of the woman (Freud, 1932). With the early stages of psychoanalysis, the mother has been made the sole person responsible for the development of the child and considered to be the source of all problems that may arise in the child (Çeler, 2013). Bowlby, one of the last representatives of psychoanalysis, reiterated the importance of motherhood for child development. He advocated a monotropic (which is often described as a mother) attitude to secure attachment of the child (Bowlby, 1973; 1980). According to Althusser (2008), 
Lacan emphasized the cultural norms in the existence of the individual. Even in the absence of a living father, it is seen that the discourse of order via culture and language continues and the progression from biological existence to human existence continues. Everything happens in the pre-built language field. In the Oedipus, this language is the father's phallus and this phallus is a sign of law and regulation (as cited in Althusser, 2008). According to Lacan, the symbolicity of the culture and society that existed before and outside the individual imposes itself on the individual. The individual is shaped by this cultural-symbolic language order and its specific structures (as cited in Hilav, 1982). With the Oedipus complex, the mother's desire is replaced by the Name of the Father. The father, by having a symbolic function, tries to get the child to leave the mother (Leader \& Groves, 1997). With new developments in psychology literature, differences in the way women are perceived have emerged and the emphasis on multiple attachment process has increased in the child's secure attachment (Sharf, 2014). In addition, it was thought that the feminist movement, together with the redefinition of the social position of women and the breaking of the legislative role of man due to the changing social conditions, has caused harm to social harmony (Collin \& Kaufer, 2015).

Badinter (1992) mentioned that a perception about maternal instinct was put forward with the change of the 18th century. Today, with the questioning of the concept of motherhood, it is noted that motherhood is re-framed through the adoption and rejection of the latter, thus making it open to debate. The fact is that preferring not to have children rather than having children does not fully coincide with social values and it often leads having children (Badinter, 1992). Based on this information it is seen that, with this change in life, the theory of maternal sanctity and the maternal instinct of every woman has been questioned, and the identification of the woman's identity has been questioned in the treatment of maternal preoccupation.

Factors related to voluntary childlessness are grouped into social context and personal decision-making factors. Social factors include poor financial situation, difficulties in the labor market, lack of adequate housing, family politics of the country, family values, and family structure. Personality factors can also be considered, namely, an effect of partner attitudes, lack of close support, and experiences in the family (Szymańska, 2013). Having children, another expression of the continuation of the generation, appears as an identity connected with women (Sever, 2015). In the definition of the family, which is the basic unit of society, heterosexual couples living together or married (even 
when legal and social positions of homosexual associations are debatable) are presumed to have children in order to be defined as a family. The maternity identity, which carries an important role in the transfer of culture and the continuity of society in terms of the identity process of the woman, goes beyond the identity of being a woman due to the sacred attribution.

According to Donovan (2013), traditional thinking defines men by what they are, and defines women by "fertility". It can be said that evaluating women through motherhood devalues women. Turkish women in traditional Turkish families are blessed through motherhood and encouraged to give birth (Özbay, 2014). In fact, in societies with traditional gender stereotypes the status of the woman in the family life increases after having a child, especially after giving birth to a boy (Bayraktar, 2011). According to Bal's study (2014), in which the media and academic texts were analyzed, it was concluded that women who have not reached the level of motherhood are exposed to a degree of social exclusion and discrediting. With the increase in urbanization and participation in the labor force, the status of women in the family has changed and the birth rate has decreased (Ataca, Sunar, \& Kagitcibasi, 1996; Kagitcibasi, 1982). In 1965, the "Law on Population Planning" was adopted and the ban on abortion was softened and then removed. At this stage, contraception was perceived as the duty of the woman and this contraception responsibility was given to the woman (Özbay, 2014). Moreover, in the 2000s women are still placed in the forefront when it comes to fertility, and policies that encourage more children are persued (TRT Haber, 18.06.2013; Yazici, 2012). Bearing a child seems to be perceived as an expression of being a woman. In terms of the identity process of women, motherhood identity, which has important roles in the transference of culture and continuity of society, goes beyond the identity of being a woman due to the attribution of holiness. Despite all these emphases on social acceptance and even regulations on being a mother, some women prefer voluntary childlessness. In such a social context, the experiences and perceptions of women who prefer voluntary childlessness are noteworthy and worthy of research. In this study, in which the phenomenon of voluntary childlessness is addressed, the aim is to examine the perceptions of married women without children on motherhood and children, and the decisions of not having children. The study aims to understand married and childless women in terms of maternity perception, child perception and the decision of not having children. 


\section{METHOD}

\section{Participations}

Data sources in phenomenology studies are individuals who have experienced and truly understand the phenomenon that the researcher wants to focus on. Therefore, it is important to study the phenomenon with individuals or groups who have experienced it in every way (Creswell, 2013). When a study group is identified, it is necessary to select individuals who are experiencing the phenomenon and who can provide rich data in this regard. For this reason, criterion sampling which is one of the purposeful sampling methods used in qualitative research is preferred and a set of predetermined criteria was determined in the first stage of the study. Being married, not having children and not wanting to have children (based on verbal declaration) were taken as criteria in this regard. The study group consisted of four married women and is limited to individuals working in the field of Psychology and Social Work. The demographic data are presented in Table 1.

Table 1. Characteristics of the Participants in the Study Group

\begin{tabular}{lllllll}
\hline Participants & Gender & Age & Mariage duration & Mariage type & Occupation & Education \\
\hline Participant 1 & Female & 40 & 23 year & Dating & Social Worker & Associate's Degree \\
Participant 2 & Female & 33 & 4 year & Dating & Psychologist & Master Degree \\
Participant 3 & Female & 30 & 2 year & Dating & Psychologist & Bachelor Degree \\
Participant 4 & Female & 36 & 14 year & Arranged & Psychologist & Master Degree \\
\hline
\end{tabular}

The participants are all adults $(\mathrm{Min}=30, \mathrm{Max}=40)$ and all participants have at least an associate's degree. The number of participants who got married after dating is three and one participant had an arranged marriage. Participants' duration of marriage ranges between two years and 23 years. While one of the participants is a social worker, the other three are psychologists.

\section{Research Design}

The research design of the current study is descriptive phenomenology. Descriptive phenomenology is one of the qualitative research designs. Phenomenological studies attempt to identify the common meaning of experiences of people in the study group (Creswell, 2013). In descriptive phenomenology studies, the data sources are individuals who are able to address the phenomenon the researcher wants to focus on (Y1ldirim \& Şimşek, 2013) and the important thing is to examine the phenomenon with individuals or groups who have experienced it in every aspect (Creswell, 2013). In this study, 
descriptive phenomenology was chosen to reveal the common meaning of the experiences of voluntary childless women. In this research Colaizzi's (1978) descriptive phenomenological investigations were followed. The aim was to gain a better understanding of the nature and quality of the phenomenon of voluntary childlessness using descriptive phenomenology.

\section{Procedure}

In this study, in-depth interviews were conducted and semi-structured interview questions were used in these interviews. (e.g. What does maternity mean to you?, How does not having a child affect your life?, How did you decide not to have a child? (What are the influencing factors?, How did the process develop?, What kind of experiences have you had in making this decision? Do you experience a dilemma about voluntary childlessness?) While semi-structured interview questions were prepared, theoretical and practical applications in addition to the opinions of two experts in the field were utilized. Discussions using open-ended questions prepared by researchers to obtain participants' views on the voluntary childlessness phenomenon lasted approximately 35-55 minutes and each participant was interviewed once. Interviews were recorded with the permission of the participants and recordings were transcribed into text by the researchers. The names of the participants were kept private.

\section{Data Analysis}

Colaizzi's (1978) descriptive phenomenology analysis steps are used in this research. In this context, the researchers first transcribed the audio recordings and read the texts several times. Researchers aimed to acquire a feeling for the participants' experiences and perceptions and extracted significant expressions that pertain directly to voluntary childlessness. The researchers then formulated hidden meanings in expressions and categorized meanings into clusters of common themes. Based on the analysis, the main themes are described in detail. The researchers tried to form a structural definition of the voluntary childlessness phenomenon. Finally, after the themes are identified the researchers engaged in a reflective process by returning to the participants for validation. Interviews and themes were sent to the participants. Feedback was obtained from the participants about the accuracy of the data for validation and to confirm anonymity. Samples of original transcriptions are presented for validation, too (Creswell, 2013). Expert-opinion was received for the consistency of analysis and revisions were made in line with the suggestions. A researcher in educa- 
tional sciences who is experienced in phenomenological researches was asked to evaluate the consistency between the data and the themes. The researcher stated that all themes were compatible with the data.

\section{RESULTS}

The main themes and sub-themes which were obtained from four married women's interviews are given in this section.

\section{The Meaning of Maternity}

Participants were asked questions about the meaning of maternity from the perspective of a woman and a wife. According to answers of the participants this main theme consists of two sub-themes. These are compulsory sacrifice and voluntary sacrifice.

Compulsory Sacrifice. The compulsory Sacrifice sub-theme is categorized under two codes: sacrifice of one's life and responsibility.

"It means giving up yourself. Directly giving up yourself, sacrifice, sacrificing your life for another living thing. For a living thing that totally depends on you."(P2).

"I see it as a responsibility, a heavy responsibility that is impossible to abandon. You know, I think it's a huge responsibility starting with pregnancy lasting until death, death of the mother. Right after the moment of conception, the woman has to think for two, live for two. I observe that in people who have given birth and who have kids. I am not a mother, I don't want to be one in any case, but motherhood seems to me a huge responsibility from my perspective." (P3).

Voluntary Sacrifice. The voluntary Sacrifice sub-theme is categorized under the codes of caretaking and forgiving.

"Maternity involves infinite compassion, love, caretaking, attention...being the source of attention... But the mother does this instinctively. She gives birth to her child with such feeling and this goes on and on." (P4).

"I mean, maternity means a lot of things like being special and creative, forgiving, protection." (P1). 


\section{The Meaning of Maternity in Social Circles}

One of the key findings of this study examines what motherhood means in the social circles of childfree women. In this context, the participants were asked questions about the meaning of motherhood for their families, husbands, friends, and how it is perceived in their work circles and in the media. As a result of the analysis, the themes of sacrifice and intimacy were obtained.

Sacrifice. The sub-theme of sacrifice is categorized under caretaking, restriction and taking the responsibility all alone.

"Motherhood means bringing a beautiful and joyful living being into the home; creating a living being that is loved by you and loves you very much; something that you sacrifice your life for without a doubt." (P2).

"For my husband, motherhood means a source of infinite love and care, a source of affection, a mother that does housework for him." (P4).

"Well you experience a loss in your work life when you become a mother. At least two or three years of your life are missing, gone. I mean caring for the child, responsibility, sickness, dedication, things like that... Since it is a process that ruins the mother's body, being a mother means to get away from work life. For a while at least, maybe 2 years, maybe 3 years..."(P3).

"Even if they live in modern or equalitarian families, women see that their freedom is restricted, it can be restricted, and they have to make big sacrifices when they become mothers." (P1).

"Mother in media... It seems to me that the media impose an image of infinite affection, infinite responsibility to women. There is particularly this aspect, namely, manipulation that makes a woman as a mother become more giving, sacrificing and ready to do everything, I think.” (P4).

"In the media, the mother is always the person who is supposed to sacrifice herself for her child, who lives for her child and the person who is declared to be solely responsible for the child. A slim, beautiful, well-groomed, nice woman has also given birth." (P4) ... "In the media, it is already expressed as if every woman has no choice but to be a mother." (P3). 
Intimacy. The intimacy sub-theme is categorized under a feeling everybody should experience and a source of love.

"Motherhood means bringing a beautiful and joyful living being into the home; creating a living being that is loved by you and loves you very much; something that you sacrifice your life for without a doubt." ... "It is a good thing for social circles. It is absolutely a feeling that all women need to experience and it is nice. So, I shouldn't be devoid of this feeling, no woman should be devoid of this feeling. Yes, there are many challenges, but for them motherhood is such a feeling that it makes all the challenges go away and you feel wonderful." (P2).

"For my husband, motherhood is a source of infinite love and care, a source of affection..." (P4).

"There is more the feeling of guilt. Related to the worry that you haven't cared enough. In the sense of spending time. I worked at a preschool. At that time I observed that being a mother is all about feeling guilt and remorse about your child, I mean, I heard a lot of mums saying 'I couldn't care enough, I couldn't spend enough time, I had to go to work, I had to work'... This is another aspect of it I think. ” (P3).

\section{The Meaning of Not Wanting a Child}

The desire for freedom and avoiding the responsibility of having a child are found to be the sub-themes that explain the meaning of not wanting a child. When the responses of the participants regarding the meaning of not wanting child theme are examined, it is clear that they responded by taking into consideration both themselves and their spouses.

Desire for freedom. Under this sub-theme, the participants emphasized the expressions of a desire to plan the future and of the fact that not everyone has the reproductive instinct.

P1: “... Being more independent, being an individual, knowing that the purpose of life is not only reproducing, knowing that every woman does not have the instinct to reproduce because I don't have it. Being more comfortable, more independent, more like an individual."

Avoiding the responsibility of having a child. Under this sub-theme, the participants emphasized the greatness of responsibility and the fear of being alone in that responsibility. 
"Maybe because it is a huge responsibility, I don't want to take that responsibility." (P2).

The above quotations display the participants' comments on the meaning of not wanting a child. Most of them see the concept as a desire for freedom and avoidance of responsibilities. Apart from these themes, some participants expressed that they did not have an instinct for having a child; they did not want to take the responsibility of having a child and they had a fear of taking responsibility of a child alone.

\section{Effects of Voluntary Childlessness}

The participants were asked questions about the effects of voluntary childlessness in terms of viewing self, economy, work life, daily life. As a result of the analysis, the themes of facilitation and restriction were obtained.

Facilitation. The sub-theme of the effects of facilitation is categorized under four codes: convenience in time management, freedom of focusing on work life, economic freedom, boasting.

"Similarly, in my daily life, there is no child waiting for me, I don't have to cook for him/her or I don't have to take care of him/her. I can sit and watch TV, I can study if I need to, I can do anything I want. If I had a child, I wouldn't be doing any of that. I mean I would have to use time differently; maybe I wouldn't be studying for a doctorate right now." (P2).

A big relief economically. I have the liberty to settle in any city, any country whenever I want. I have the luxury not to work in a place which makes me unhappy. This is because I don't have any economic obligations. If I had a child s/he would need more and more. This gives me great freedom, an incredible freedom to quit." (P1).

"I think I did the right thing. I say to myself you are doing good, not having something you don't desire much, something you don 't desire." (P3).

Restriction. The restriction sub-theme is categorized under two codes: challenges of working with children and feeling incomplete and questioning.

“Working as a psychologist I don't have problems with children and we make progress during the sessions, but mothers always ask the same question "Do you have a child?", "Do you have a child?". "No, not right now," I answer. When I say that they 
immediately think I can't understand their situation and a prejudice arises... If you work with children, having a child is an advantage in your work life. Not having a child becomes a major disadvantage when you work with children." (P4).

"You know I sometimes feel incomplete. Most of the time, the reason for this is society. I mean it is because of society, but sometimes I ask myself 'Should I have a child?' But I still know I can't do that. Sometimes not having a child, not wanting a child, actually makes me question "Am I incompetent and is that why I don't want it?" or "Am I too selfish to have a child?" This is a huge sacrifice for me, that's why I don't want it." (P2).

As seen above, the effects of voluntary childlessness are grouped under the categories: facilitation and restriction. When these categories are examined closely, an emphasis on ease of time management, freedom to focus on business, economic freedom, difficulties in working at child related jobs was pointed out. Some of the participants seem to be pleased with and proud of their decisions while others express that they feel incomplete and restricted and they question their decisions from time to time.

\section{The Decision of Voluntary Childlessness}

When the responses of the participants regarding their voluntary decision to be childless are examined, it is seen that they responded by taking into consideration the aspects of emotional reasons, economic reasons, witnessing negative experiences, and worry about the future of the child. This theme can be categorized under the sub-themes of Personal Reasons and Social Reasons.

Satisfying the Feeling of Maternity in other Ways. When the responses of the participants regarding this sub-theme are examined, it is clear that they stated that they experienced this feeling because they took care of other children (siblings, children of friends) in their social surroundings.

"The age gap is pretty wide between me and my sister, so during the labor and afterwards I was like a mother... So I experienced a little bit of motherhood with her, and I know what it is like to be a mum. I guess I didn't want to have a child. Because I felt that love, I mean the experience, I didn't want to feel it again." (P1).

Worries About Being a Mother. The sub-theme of social reasons consists of the following codes: challenges of pregnancy and labor, change in romantic relationships, mother-child experiences, worry about the future of the child and economic reasons. 
"I think that it ruins the woman physically. I mean C-section is hard, it is really hard, but normal delivery is hard, too. I think it is really hard for the body." ... "Crying children, women who cannot calm their children, children who don't sleep, mothers who cannot make their children sleep... I know them, those images, and such situations would be really hard for me." (P3).

"The relationships I see in my social environment affected me very much. Mother-father-child relationship maybe, in fact my brother's relationship. I have a non-related, spiritual brother. I closely witnessed his relationship with his wife after their child was born and it got worse. They didn't seriously think about divorce, but both of them didn't love each other anymore. It was an awful example of how they consumed the relationship by criticizing each other over childcare. It is not healthy... After seeing how our relationship goes well, and seeing other people's relationships, it becomes comfortable and enjoyable to live like this." ... "It is a really bad idea to have a child just because of wanting a child, just because I will be satisfied or just because I want to be a mother... It is not just about you, a child should not be born into the society we live in. The belief that the world is not just and good... I see and experience all of these things." (P2).

"If I had much better economic status, maybe taking this decision would be easy" (P4).

As shown above, participants gave various answers to the question "How did you decide not to have a child?" Some of them focused on satisfying the feeling of maternity in other ways whereas others presented worries about being a mother. The major themes of these two categories included 'challenges of pregnancy and labor, feeling economically inadequate, worries about the future of the child, and witnessing the negative experiences of labor and infancy, or hearing such experiences. In addition, it is clear that participants avoided the challenges created by forming a balance. A participant expressed this view as follow: '...for me the most important concern is what kind of a person I would raise, what if s/he becomes a bad person, what if I fail...?'

\section{Social Reactions to Voluntary Childlessness}

When the participants were asked about the responses of their social surroundings regarding their decision to be childless, it is clear that they responded by considering their own family, spouse's family, friends, and colleagues. Their responses were categorized under the codes of: challenges of working with children, feeling incomplete and questioning. This theme is not divided into sub-themes. 
“...People around me don't get it. They nicely and little by little state their ideas that we will need a child when we get old, we should have a child, and we can't do without a child. There are people that desire us to have a child in my husband's family. They put a bit of emotional pressure on us, and they will do so in the future." (P1).

“Umm selfish, yes you're judged as selfish. They directly judge you. You don't want a child, you're selfish. I wonder what the harm in being selfish is. It can be, I can be selfish, but you are judged immediately by people around you. You are immediately labeled, that's bad. I mean, you cannot say that you don't want it, that you are not ready for this or that you cannot do it. ... I hear a lot that people around me saying that if you don't have a child, you will regret it, you will be alone in the future...' I often hear statements like: 'You're a woman, motherhood is instinctive for a woman, why you don't have it. 'It is like something that every woman should do. I hear this from people of high intellect to low intellect." (P4).

"At first we got reactions from both our social environment and from our families, those of the latter being dominant. There were reactions such as 'You have a child, we will take care of him/her'. But they got used to it, they accepted it." (P2).

These quotations display the findings about the reactions to the decision of childlessness. Participants expressed that they faced emotional pressure, alienation and criticism; they were not understood and were labeled as selfish and they were judged. One participant stated that despite initial reactions, her social circles accepted the fact that she would not have a child.

\section{Dilemmas Experienced in the face of Voluntary Childlessness}

This theme examines the dilemma surrounding voluntary childlessness. The dilemma theme consists of two codes: fear of future regret, questioning the decision and the idea that it is instinctive. This theme is not divided into sub-themes.

"Now, I think if being a woman equals being a mother, I don't feel that way now, but in the future, when I am 50 then will I feel so? Will I really feel that way? Will I think that 'oooh I should have had a child, this is the reason my existence? I don't know, and not knowing this worries me." (P4).

Right now I am determined, but later... when G. (a close friend) was pregnant and had her first child and N. (sister) was pregnant, at those times I seriously questioned 
myself. Now a friend of mine is pregnant, and one of my closest friends is also pregnant, and at this moment I realize something, it was just like a wave in my head that comes and goes, like a breeze. But in my lifestyle I don't want motherhood."(P2).

"Sometimes I wonder if I should want it and then I don't know if I want it and I repress the question... As you research, you see that it is an instinctive phenomenon; we are coded that way, with desires and stuff. This is confusing for me. But there isn't any feeling waking inside me about this." (P3).

As shown above, only one participant answered 'no' to the question of 'do you experience a dilemma about voluntary childlessness?' whereas the others assert that they do experience a dilemma. These dilemmas consist of the questioning of the decision due to social reactions and the fear of future regret.

\section{DISCUSSION}

This study, in which the phenomenon of voluntary childlessness is addressed, examined the perceptions of married and voluntarily childless women towards maternity and child bearing, and the decisions not to have children.

As a result of the analysis of the data, the main theme, that of "the meaning of maternity", was revealed through the sub-themes of 'voluntary sacrifice' and 'compulsory sacrifice'. Answers given to the question "What does maternity mean to you?" merge under the concept of sacrifice. However, the statements of the participants regarding sacrifice differ from each other. Maternity represents caretaking and voluntary sacrifice including forgiveness for some participants, whereas for others of them, it means a responsibility that is impossible to abandon and compulsory sacrifice that includes sacrificing your own life.

The emotional risks of maternity reproduce the social expectations regarding women and put them into the position of nurturing and caring (Settle \& Brumley, 2014). Badinter (1992) asserts that there is not such a concept as "maternity instinct" and maternity is an acquired behavior. In the study conducted with voluntarily childfree women, (Settle, \& Brumley, 2014) found that, for voluntarily childfree women, maternity means life-long commitment and being a victim, and having a child is a destructive process for them. In this study, perceptions of maternity revealed that childcare is a burden on women as a result of gender roles and women are expected to give care to children by sacrificing their lives. 
As a result of the interviews with the voluntarily childless women, the sub-themes of sacrifice and intimacy were revealed under the theme of 'the meaning of maternity in social circles'. Women who have reached the level of motherhood are sanctified and those who have not are exposed to a degree of social exclusion and discrediting (Bal, 2014). As psychoanalysis has risen in the psychology field, motherhood has been presented as the mere person in charge of a child's development and the source of all problems observed in a child (Çeler, 2013). Bowlby, one of the pioneers of attachment theory, adopted a monotropic approach in attachment and emphasized that the attachment object is primarily the mother (Bowlby, 1973). The feminist approach, which proposes multiple attachment, argues that the mother has the priority in the hierarchical process (Collin \& Kaufer, 2015). In a study by Settle and Brumley (2014) voluntarily childfree women were interviewed and it was found that motherhood was perceived as a sacrifice and a risky situation. In this study, findings related to the meaning of maternity in the family show that the perception that childcare is only the mother's responsibility transforms into emotional, social and physical pressure on the mother, and the mother has difficulty in coping with the challenges of this perception. The perception that motherhood equals sacrifice causes worries about being a mother. These worries make the mother feel the right to intervene in the child's life in exchange for her sacrifices. In addition, this sacrifice increases expectations from the child. Seccombe (1991), in a study focusing on couples that choose voluntary childlessness, found that contrary to the expectation that women prioritize the concept of family, men are more pronatalist compared to women. It was found that men cared about having a child more than women and they were more willing to be parents. In a study carried out by Miettinen, Rotkirch, Szalma, Donno and Tanturri (2015), it was found that men with high education degrees did not want to have a child and men had a greater desire to have a child compared to women. In a study about voluntarily childfree couples, Rosemary (1991) detected that men preferred to spend spare time with their wives to protect and enhance the relationship.

The findings of this study related to the meaning of motherhood for husbands reveal that husbands of the participants see motherhood as being respectful, being the caregiver and being the provider of love, yet also as a situation of torment. It is regarded that views of being respectful and being caregiver seem to be in line with the gender role attributed to women as the sole caretaker of children. It is noted that childcare is described a challenging and tormenting process burdened on women rather than a shared responsibility 
of women and men. Therefore, motherhood is considered to be a respectful choice due to the agreed perception that it is a challenging process. In addition, as is stated in ethics of care (Gilligan, 1982), the woman is the provider of love and is the caregiver.

In a study conducted by Gökdemirel, Bozkurt, Gökçay and Bulut (2008), it is found that women have concerns about child care and nutrition right after they go back to work; they even have problems with employers in using legal rights for child care; they need to make serious changes in their lives; they face status deprivation and dismissal. In this study, participants were asked to comment on the meaning of maternity in work life according to their observations of the workplace. The findings indicate various statements such as feelings of guilt, being blamed by the child, excessive responsibility of childcare, experiences of loss in work life and stress on restrictive aspects of motherhood. These findings are similar to the ones in the literature in that they also state that working mothers blame themselves and are blamed by their children. This is also a reflection of gender roles that see woman as the only caretaker of the child. In addition to other responsibilities imposed by gender roles, the woman is also responsible for the care of the child and other requirements in her life due to her status as a mother. Besides, the fact that there are not enough legal regulations in the working life is another notable aspect for women.

Development models acknowledge being a parent as a developmental stage to be completed. In these models, it is suggested that adult individuals should go through the marriage phase and then into the parental stage (DeLyser, 2012). Ruddick (1980) states that motherhood is acquired through socialization. From the time of their birth, women are surrounded by thoughts and behavioral patterns accepting her as a potential mother. From the beginning of their lives, women are exposed to and raised with such values as childcare, attention, compassion, sacrifice, etc. Thus, motherhood finds its presence in women through social construction. In the study conducted, while some of the views of the perception of motherhood in the social environment are similar to the literature, there also are views, which emphasize the creative aspects of the womanhood and motherhood as a feeling that every woman should experience. On the other hand, the study showed that there are views in the social environment that all responsibilities should be undertaken and accomplished by the mother alone and that she should be a vessel of sacrifice, which is imposed through social construction. It is also seen that the intense emotional-physical fatigue of the mother causes burnout; being responsible for the childcare alone destroys a woman's personal space and leads to the restriction of her freedom. 
In the study conducted by Türkdoğan (2013), it is detected that the sexist language used by the media reproduces the patriarchal system and sanctifies motherhood. By sanctifying motherhood, the media exhibits an attribution that neglects being a human and a woman first. Language used in the news leads to victimization of women and poses a dilemma by sanctifying them through motherhood. The woman takes on a holy reference when she is a mother, but being a woman is presented as being a victim or as a visual object. Thus, motherhood is made inevitable. Gittins (1985) states that motherhood is regarded as the "natural destiny" of women, but women with illegitimate children are not approved in society. Based on this view, Gittins (1985) express that motherhood is a social concept and it is constructed. Findings related to the presentation of motherhood in the media show similarities with the literature. The statements of the participants include the presentation of motherhood as a necessary life process, the presentation of woman as a visual material, presentations of the mother as a caring and sacrificing person, which is quite compatible with gender roles.

In the current study, as a result of the analysis of the data, we discovered the main theme, namely "the meaning of not wanting a child" through the sub-themes of "desire for freedom" and "avoiding the responsibility of having a child". There are studies supporting these findings in the literature. For instance in the research conducted by Engwall (2014), the difficulty of parenting and establishing a healthy relationship with the child, the responsibility of child care, the burden of child care falling on the mother, the risk of inheritance of genetic disorders and the anxiety of taking a step into not only being a parent but also adulthood are the main reasons for voluntary childlessness. In the research carried out by Rosemary (1991), the researcher identifies several reasons for being voluntarily childless, namely, personal freedom, freedom of travelling, and spending time for oneself. In keeping with the literature, it is seen in the research that the main reasons for not wanting children are freedom and avoidance of the responsibility brought on by child rearing. It is thought that being the only person responsible for child rearing is an important factor in avoiding this responsibility. New arrangements in daily life due to the child and the restriction of freedom of movement are among the main reasons why women choose voluntary childlessness. It is seen that being a woman is more important than being a mother and individual freedom has vital importance for the participants.

When the responses of the participants to the question "How does not having a child affect your life?" were examined, the theme of the effect of voluntary childlessness was 
expressed in the sub-themes of restriction and facilitation. Examining the lifestyles and features of voluntary childfree people, it is found that they like adult life and its freedom (Hird, \& Abshoff, 2000; Moulden, 1991; Seccombe 1991). The study also revealed that voluntarily childfree women are well-educated; they have nice jobs and they are good at social communication (DeLyser, 2012). According to Rosemary's (1991) research, the advantages of being childfree are expressed as having more freedom, flexibility, less anxiety, greater mobility, greater independence, less responsibility, better relationships with spouse, and professional and financial advantages. However, it has been pointed out that there is a disadvantage in not being able to experience the favorable sides of child rearing and also in not being a family. There are also other disadvantages such as financial risk, unequal marriage, career etc. (Settle \& Brumley, 2014). The findings of this research are similar to the literature. The day-to-day effects of being a childfree person are facilitated by the ease of time management and the simpler handling of housework. The impact of being a childfree person in the social environment is manifested by the fact that more time is allocated to oneself, and to peers, hobbies, social environment and non-governmental organizations. Given the effects of voluntary childlessness on work life, it appears that one participant finds being childfree disadvantageous in jobs in which work with children is involved. On the other hand, many of the participants point out that childlessness is an advantage in business life because they can work comfortably and gain more experience. Similarly, participants also state that being childfree gives economic freedom and reduces future anxiety. Some participants acknowledge their decision of not having a child is something they are content with and proud of. Some of them, on the other hand, occasionally feel themselves missing something and question their decision of childlessness.

Participants' answers merge under different themes regarding the question "What does maternity mean in your family?" It is clear that the participants' families acknowledged maternity as caring for the child and taking all the responsibilities of her/him, having control over the child, feeling concerned about the child and being sacrificial. Findings related to the meaning of maternity for husbands as exemplified above are that motherhood expresses the source of love and sacrifice. In addition to these views, there are participants indicating that motherhood means a process that is hard to bear. It also means to relinquish freedom.

In addition to sacrifice and intimacy it can be said that a feeling of guilt is experienced by mothers in their work life. It was shown that daily life reflections of mother- 
hood in work life denote an increase in responsibilities, deficiencies in work life and a barrier to work life. Maternity in social circles is found to be sacrificing, enduring, and restrictive. In addition, mothers are acknowledged as being alone in caring for the child and they are not supported by fathers at all. There are also views that all women should experience this wonderful feeling of being a mother. Lastly, according to the participants, the media depicts an ideal mother as the owner of infinite affection, as a person always ready to sacrifice everything, and one who associates maternity with sacrifice. Another reflection of a mother in the media is related with her looks. Some participants indicated that a mother should never give up being well-groomed.

There are studies that support the decision of voluntary childlessness, another theme of the current study, and its sub-themes, namely, satisfying the feeling of maternity in other ways and worries about being a mother. For instance, in the study conducted by DeLyser (2012), it was determined that voluntarily childfree women have a strong knowledge and skill of childcare, nutrition and communication with children. These individuals are interested in the children of their friends and family members in their social environment. It has been seen that these individuals develop a complex attachment both to their partners and to the social relationships around them and to their interest in children in this social environment.

The participants of this study also seem to be providing for their need of child love and care from their family and social environment. In the study by Settle and Brumley (2014), it appears that voluntarily childfree women do have a belief that they cannot be good mothers and that they do not have maternal instincts. They also maintain the belief that they cannot provide a balance between giving care, giving the child the opportunity to move freely and being patient. It seems that there are concerns about child-raising as a result of observing mothers. The research conducted by Rosemary (1991) included freedom, flexibility, less anxiety, greater independence, less responsibility, better relationships with spouse, and professional and financial advantages. Participants expressed that they are very happy with their partners and that they do not want to risk this and that they are worried about sharing their partners with a child. In this research, having a child is thought to have a negative effect on the relationship with the partner, which was in keeping with the literature. It is seen that the concerns of childfree women regarding marital harmony and the child's future have an important role in the decision of childlessness. It has been observed that pregnancy, giving birth, observations of childcare 
from the social environment and from the family, and childcare experiences are significant dynamics for women in choosing childlessness.

Another finding of the study is social reactions to voluntary childlessness. Badinter (1992) states that preferring not to have children rather than not having children does not fully coincide with social values and often leads to having children. It is also found in this study that women who are voluntarily childfree are exposed to similar criticism and oppression. It seems that they are subjected to emotional pressure and criticism with the words "I cannot be an aunt, cannot love my grandchild" from relatives and close relatives in this decision. Similar results emerged in the study conducted by Somers (1993); it was found that relatives have more negative attitudes towards being childlessness than their parents and friends. It was also stated that relationship satisfaction of couples without children are high. In a study conducted by Brown (2016), it was determined that the labeling of voluntary childfree women is related to cultural and social expectations. The role of religious background and socioeconomic status is great in this regard. Especially gender roles related to motherhood have a significant share in labeling. It has been demonstrated in research that voluntarily childfree women are more likely to be exposed to isolation than women with children. This study reveals the reaction of the social environment on women in the light of the belief that having children is the initial norm for women. In addition, the social environment applies oppression and labeling on the voluntarily childfree woman.

The last finding of this study concerns dilemmas experienced in regard to voluntary childlessness. In the literature, there are studies stating that voluntarily childless women have questions about their decision to be childless from time to time. In the study conducted by DeLyser (2012), it was detected that the decisions of women who are approaching middle age and 40 years of age about whether to have children or not have re-emerged and been processed over time. It is seen that decisions about not having children come back in the life cycle, and voluntarily childfree women process the decision regarding the parental decision mentally and socially as well as observing parents and imagining what kind of life it would be if they had children. Another finding is that women who voluntarily decide not to have children do not have any feelings of remorse. In the study conducted by Brown (2016), it was found that voluntarily childfree women experience childlessness as a part of their identity, rather than a decision-making process. The study showed that voluntarily childfree women felt different and special about themselves as a child, which may be defined as a step towards becoming a person 
who is more open to differences. In the current study, in the context of the dilemmas surrounding the decision not to have children, it appears that the dilemmas of the participants are manifested in the fear of questioning and regretting their decisions due to the reactions of the wider circle. It is stated that voluntarily childfree women question their decision during the pregnancy of a woman who has a close relationship with them. In addition, one of the participants indicated that she concludes motherhood is instinctive after reviewing the related research. Nonetheless, she stated that she does not have any feeling towards having a child. One participant stated that she was clear in her decision and did not have any dilemmas.

Couples are expected to have children after marriage within the normal pattern of life. In this case, women encounter more intense pressure to have children than men. Maternity is seen as a prerequisite for being a woman. In Turkey, when couples get married, the first question they face is "When will you have children?" Indeed, Turkey is a country where the proportion of young people is quite high. The rate of people in the 0-14 age group is $23.7 \%$ and this rate is quite high compared to European countries (Eurostat, 2018). On the other hand, although few in numbers, some women do not want to have children, therefore they choose voluntary childlessness. Therefore, the phenomenon of voluntary childlessness is noteworthy. There is a common belief that a good mother must be devoted and caring (Bal, 2014; Yorukoglu, 1997). At the same time, the mother must continue to combine her social life and career and should not neglect her personal care either (Bagli \& Sevim, 2007; Beyinli, 2014; Isik, 2015).

It looks like motherhood, a socio-cultural phenomenon, is a taboo because of its sacredness, and a woman cannot be imagined as childfree. It is seen that women who choose childlessness feel themselves unrecognized and that their social environment has a hard time accepting these preferences. In the framework of this study it was observed that this instinctive attitude about maternity and perceptions on having children is still ongoing and that the pressure to be a mother has been preserved in the social environment. It is also clear from the study that voluntarily childfree women define childlessness as freedom in many areas of life (economic, romantic relations, social relations). With this study, the voice of voluntarily childless women and women's rights to decide about their own body has now been included in the literature. These women feel pressure about their decisions to be childless, and when they found out we were doing research on this subject, they thought we were their voices. 
The limitation of the study was the difficulty in reaching voluntarily childless women. Another limitation of this study is that voluntary childlessness is only viewed from a women's perspective. It is recommended to work as couples for a wider view and in order to reveal the experiences of men and women as couples without children. In future studies, it is recommended that both spouses be included in the study. It is also recommended that an assessment be made on how the decision of childlessness is reflected in the relationship between spouses, especially in the context of the concept of freedom.

\footnotetext{
Peer-review: Externally peer-reviewed.

Conflict of Interest: The authors have no conflict of interest to declare.

Grant Support: The authors declared that this study has received no financial support.
}

Hakem Değerlendirmesi: Dış bağımsız.

Çıkar Çatışması: Yazarlar çıkar çatışması bildirmemiştir.

Finansal Destek: Yazarlar bu çalışma için finansal destek almadığını beyan etmiştir.

\section{References/Kaynakça}

Althusser, L. (2008). Psikanaliz üzerine yazılar Freud ve Lacan (İ. Keskinoğlu, Trans.). İstanbul: İthaki. Ataca, B., Sunar, D., \& Kagitcibasi, C. (1996). Variance in fertility due to sex-related differentiation in child-rearing practices. In H. Grad, A. Blanco, \& J. Georgas (Eds), Key issues in cross-cultural psychology (pp. 331-343). Lisse: Swets \& Zeitlinger.

Badinter, E. (1992). Kadınlık mı? Annelik mi? (A. Ekmekçi, Trans.). İstanbul: İletişim.

Bagli M. T., \& Sevim S. A. (2007). Popüler Anababalık: Aile Dergileri Üzerine Bir Araştırma. In N. Ahioglu \& N. Güney (Eds,) Popüler Kültür ve Çocuk (pp. 127-158). Ankara: Dipnot Yayınları.

Bal, S. (2014). Reklamların Eskimeyen Yüzü "Muhteşem Annelik": Anneler Günü Reklamları Örneği. Ankara Üniversitesi İlef Dergisi, 1(2), 59-85. doi: 10.24955/ilef.106592

Bayraktar, S. (2011). Makbul Anneler Müstakbel Vatandaşlar. Ankara: Ayizi. Beyinli G. (2014). Elleri tılsımlı: Modern Türkiye'de ebelik. Ankara, Ayizi Kitap.

Blackstone, A., \& Stewart, M. D. (2012). Choosing to be childfree: Research on the decision not to parent. Sociology Compass, 6(9), 718-727. doi: 10.1111/j.1751-9020.2012.00496.x

Bowlby J. (1973). Attachment and Loss: Separation, anxiety and anger. New York: Basic Bowlby, J. (1980). Attachment and loss. New York: Basic Books.

Brown, L. (2016). Childfree women: Comparing narrative themes. Doctoral Degree Of Psychology. Adler University Chicago United States.

Colaizzi, P. (1978). Psychological research as the phenomenologist views it, in R. Valle and M. King (eds) Existential-phenomenological Alternatives for Psychology. New York: Oxford University Press.

Collin, F., \& Kaufer, I. (2015). Feminist güzergâh (G. Acar-Savran, Trans.). Ankara: Dipnot.

Costa D. L. (2000). From mill town to board room: The rise of women's paid labor. Cambridge, MA: National Bureau Of Economic Research Working Papers.

Creswell, J. W. (2013). Nitel araştırma yöntemleri: Beş yaklaşıma gore nitel araştırma ve araştırma deseni. Mesut, B., \& Selçuk B. D. (Eds.). (M. Aydın, Trans.) Ankara: Siyasal Yayınları. 
Çeler, Z. (2013). Annenin serüveni: Kadının anne olarak toplumsal kurgulanışı. Ankara: Doğubatı.

DeLyser, G. (2012). At midlife, intentionally childfree women and their experiences of regret. Clinical Social Work Journal, 40(1), 66-74. doi: 10.1007/s10615-011-0337-2

Donovan, J. (2013). Feminist Teori. İstanbul: İletişim Yayınları.

Engwall, K. (2014). Childfreeness, parenthood and adulthood. Scandinavian Journal of Disability Research, 16(4), 333-347. doi: 10.1080/15017419.2013.781955

Eurostat, (2018, September, 9). Population by age group. Retrieved 9 September, 2018 from https:// ec.europa.eu/eurostat $/ \operatorname{tgm} /$ refreshTableAction. do $? \mathrm{tab}=$ table \&plugin $=1 \&$ pcode $=\operatorname{tps} 00010 \&$ language $=\mathrm{en}$.

Freud, S. (1932). New Introductory lectures on psycho-analysis. London: The Hogart Press.

Gilligan, C. (1982). In a Different Voice: Psychological Theory and Women's Development. Cambridge, Mass.: Harvard University Press.

Gittins, D. (1985). Aile sorgulanıyor (Y. Zihnioğlu, Çev). İstanbul: Pencere Yayınevi.

Goldin, C. (1991). The role of World War II in the rise of women's employment. American Economic Review, 81(4), 741-756. doi: 10.2307/2006640

Gökdemirel, S., Bozkurt, G., Gökçay, G., \& Bulut, A. (2008). Çalışan annelerin emzirme sürecinde yaşadıkları: Niteliksel bir çalışma. Çocuk Dergisi, 8(4), 221-234.

Hilav, S. (1982). Lacan üzerine. Yazko Felsefe, 1, 138-148.

Hird, M. J., \& Abshoff, K. (2000). Women without children: A contradiction in terms?. Journal of Comparative Family Studies, 31(3), 347-366. doi: 10.3138/jcfs.31.3.347

Isik, S. Y. (2015). Küresel kültürel değişim ve 'yeni 'annelik: Ankara Kamil Ocak Mahallesi örneği. Eğitim Bilim Toplum, 13, 48-75.

Kagitcibasi, C. (1982). The changing value of children in Turkey. Honolulu: Hawaii, East-West Centre.

Koçyiğit, O. T. (2012). İnfertilite ve sosyo-kültürel etkileri. İnsanbilim Dergisi, 1(1), 27-37.

Leader, D., \& Groves, J. (1997). Lacan yeni başlayanlar için (G. Ç. Güven, Trans.). İstanbul: Milliyet. Miettinen, A., Rotkirch, A., Szalma, I., Donno, A., \& Tanturri, M. L. (2015). Increasing childlessness in Europe: Time trends and country differences. Stockholm: Stockholm University Families and Societies Working Paper 33.

Moulden, R. I. (1991). A descriptive study of the childfree alternative to a family lifestyle. (Unpublished Master Thesis) Department of Educational Psychology. Edmonton, Alberta.

Özbay, F. (2014). Demografik Dönüşüm Sürecinde İktidar, Kadın ve Aile. In Ulrike Dufner ve Semahat Sevim (Eds.) Başka Bir Aile Anlayışı Mümkün Mü? (pp. 106-111). İstanbul: Heinrich Böll Stiftung.

Rosemary, I. M. (1991). A descriptive study of the childfree alternative to a family lifestyle. (Unpublished Master Thesis). Department of Educational Psychology, Edmonton. Available from ProQuest Dissertations and Theses. (UMI No. MM66668).

Rowbotham, S. (1989). To be or not to be: the dilemmas of mothering. Feminist Review, 31(1), 82-93.

Ruddick, S. (1980). Maternal Thinking. Feminist Studies, 6(2), 342-367. doi: 10.2307/3177749

Seccombe, K. (1991). Assessing the costs and benefits of children: Gender comparisons among childfree husbands and wives. Journal of Marriage and the Family, 53(1),191-202. doi: 10.2307/353143

Settle, B., \& Brumley, K. (2014). 'It's the Choices You Make That Get You There': Decision Making Pathways of Childfree Women. Michigan Family Review, 18(1), 1-22. doi: 10.3998/ mfr.4919087.0018.102

Sharf, R. S. (2014). Psikoterapi ve psikolojik danışma kuramları kavramlar ve örnek olaylar. (N. Voltan-Acar, Trans.). Ankara: Nobel Yayınları. 
Sever, M. (2015). Kadınlık, annelik, gönüllü çocuksuzluk: Elisabeth Badinter'den Kadınlık mı Annelik mi?, Tina Miller'dan Annelik Duygusu: Mitler ve deneyimler ve Corinne Maier'den No Kid üzerinden bir karşılaştırmalı okuma çalışması. Fe Dergi: Feminist Eleştiri, 7(2), 71-86. doi: 10.1501/Fe0001_0000000144

Smith, J. A. (Ed.) (2003). Qualitative Psychology: A Practical Guide to Research Methods. London: Sage.

Somers, M. D. (1993). A comparison of voluntarily childfree adults and parents. Journal of Marriage and the Family, 55(3), 643-650. doi: 10.2307/353345

Szymańska, J. (2013). The childless by choice in perception of young adults. Family Forum, 3 (pp. 79-95).

TRT Haber (Haber Program1), Türkiye Radyo ve Televizyon Kurumu, 18.06.2013.

Türkdoğan, Ö. (2013). Ana akım medyada annelik miti. Kadın Araştırmaları Dergisi, 13(2), 35-59.

Whitford, M. (1991). Luce Irigaray: Philosophy in the feminine. New York: Routledge.

Yazici, B. (2012). The return to the family: Welfare, state, and politics of the family in Turkey. Anthropological Quarterly, 58(1), 103-140. doi: 10.1353/anq.2012.0013

Yıldırım, A., \& Şimşek, H. (2013). Sosyal bilimlerde nitel araştırma yöntemleri. Ankara: Seçkin Yayıncilik.

Yorukoglu, A. (1997). Değişen toplumda aile ve çocuk. İstanbul: Özgür Yayınları. 
